\title{
Investigating ESP Instructors' Beliefs and Attitudes and Their Classroom Practices
}

\author{
Yousef Rajabi* \\ English Department, Kermanshah Branch, Islamic Azad University, Iran \\ Corresponding Author: Yousef Rajabi, E-mail: Josef.rajabi@gmail.com
}

\section{ARTICLE INFO}

Article history

Received: September 22, 2017

Accepted: November 26, 2017

Published: January 05, 2018

Volume: 7 Issue: 1

Advance access: December 2017

Conflicts of interest: None

Funding: The research is

financed by Islamic Azad

University, Kermanshah Branch.

\begin{abstract}
This study was an attempt to examine Iranian ESP teachers' beliefs and their ties with classroom practices. To do so through convenient sampling, twenty five ESP teachers teaching English for specific purposes in different disciplines such as Chemistry, Accounting, Mathematics, and Law at Islamic Azad University, Kermanshah branch, in Kermanshah city, Kermanshah, Iran participated in this study. Since the participants' gender was not among the aims of this study, its probable effects were controlled. In order for the data to be as reliable and valid as possible, the participants were interviewed and asked to fill in the questionnaire at times when they had free time. The researcher had the teachers fill in the questionnaire. Then, they were interviewed in their free times most often outside the university. The findings of the study revealed that there was no relationship between ESP teachers' beliefs on their teaching practices in the classroom.
\end{abstract}

Key words: English for specific purposes, teachers' beliefs, Classroom practices

\section{INTRODUCTION}

\section{Background}

As the world's international language, English has become the primary means of communication among many disciplines and professions around the globe. This highlights the importance of the English for Specific Purposes and more particularly, the increasing concern for its subcategory; i. e., English for Academic Purposes (EAP). More importantly, Essen (2000) views ESP as one of the main purposes for the existence of English as an International Language (EIL). As Widdowson (1997) puts it, "EIL and ESP are coterminous,otherwise it would not have spread, otherwise it would not regulate itself as an effective means of global communication. Otherwise, there would, for most people, be little point in learning it at school or university" (p. 144).

In so far the actual classroom context is concerned, there seems to exist certain strong ties between the ESP teachers' beliefs and various aspects and dimensions of their classroom actions. Nevertheless, there is no empirical research to date examining Iranian in-service ESP teachers' beliefs, attitudes and actions leaving this area allegedly unexplored.

In recent years the focus of research on teaching and teacher education has somehow shifted from teachers' behavior to areas of cognition that are the basis of such behavior. More specifically, teachers' beliefs and attitudes have been recognized as a significant factor in teaching (Stuart \&Thurlow, 2000; Renzaglia et al., 1997). The so-called shift in research on teachers' practices has brought about considerable insights into teachers' beliefs, which in turn has led to several research reviews (Pajares, 1992; Richardson, 1996; Stuart \&Thurlow, 2000; Wenden, 1999; Woods, 1996). A review of literature on the issue indicates that teachers' beliefs have a critical impact on the way they teach in the classroom, learn how to teach, and perceive educational reforms (Borg, 2001). It is within this framework that research on English as a second/foreign language (ESL/EFL) teachers' beliefs has emerged as a corollary of the framework initiated by the broader educational research.

In addition, research on ESL/EFL teachers' beliefs is particularly important in contexts where English is taught for specific purposes; i. e., English for Specific/Academic Purposes (ESP/EAP). The beliefs ESP/EAP teachers' hold seems to have a lot to do with the way they teach, the decisions they make, and classroom practices they follow, among others.

\section{Statement of the Problem and Purpose of the Study}

Since the artificial classroom situations in TTC (teacher training courses) have been under question by the teachers who find them completely different from the real classroom cases, there has been more tendency to scrutinize teachers' beliefs and experiences to figure out the more natural reality in order to be able to feel the problems of teaching and teacher education programs naturally.

\section{Research Question \& Hypothesis}

1. Do in-service ESP instructors' attitudes and beliefs affect their real classroom practices? 
Based on the research question just stated, the following hypothesis was formulated.

Since the study's main question is qualitative in nature, no hypothesis is put forth.

\section{REVIEW OF LITERATURE}

\section{The Advent of ESP}

These days ESP is a major activity in the academic and business all around the world. It is considered as an enterprise which is included in education, training and practice, and drawing upon three major realms of knowledge: language, pedagogy and the students'/participants' special areas of interest (Hutchinson and Waters, 1987; West, 1998). From the early 1960's, in Hutchinson and Waters' view, today in order to become one of the most prominent areas of (English as a foreign language) EFL teaching, English for Specific Purposes (ESP) must be continued. It provides its development in increasing number of universities offering an MA in ESP and in the number of ESP courses offered for overseas students in English speaking countries. There is now a well-established international journal dedicated to ESP discussion, "English for Specific Purposes: An international journal" (ibid). Robertson and Nunn (2010) proposed that, for a long time, in the shadows of the Second Language Acquisition field and the never- ending circuit of SLA conferences across the world ESP has been remained. A definition of ESP, in Strevens' view, needs to distinguish between four absolute and two variable characteristics including absolute and variable characteristics.

\section{Claims of ESP}

ESP focuses on the learner's needs, waste no time, is relevant to the learner, is successful in imparting learning, is more cost-effective than 'General English'. Subsequent to Strevens' definition, Dudley-Evans (1998) proposed another definition which was largely adapted from Strevens' definition. The definition Dudley-Evans proposes seems to enjoy some improvements over Srevens' (1988) by removing the absolute characteristic that ESP is "in contrast with 'General English', and has revised and increased the number of variable characteristics. The division of ESP into absolute and variable characteristics, in particular, is very helpful in resolving arguments about what is and is not ESP. From the definition, ESP can neither it necessarily refers to specific discipline, nor does it have to be aimed at a certain age group or ability range. ESP should be seen simply as an 'approach' to teaching, or what Dudley-Evans describes as an 'attitude of mind'. Such a view echoes that of Hutchinson and waters' (1987) who point out, "ESP is an approach to language teaching in which all decisions as to content and method are based on the learner's reason for learning" (p. 19).

One defining feature of ESP which has contribution to its emergence is that language education must be based on the needs of students. Different courses for various groups of learners must be provided, because learners in different fields have different needs. Consequently, ESP has to be divided into different branches.

\section{METHOD}

\section{Participants}

The total number of ESP teachers both males and females who participated in this study was 25 . The teachers were teaching English for specific purposes at Islamic Azad University, Kermanshah branch, in Kermanshah city, Kermanshah, Iran. The participants were selected according to the type of the ESP course they were teaching on the basis of availability sampling.

The number of male teachers was almost equal to the number of female participants; that is, the total number of male participants was twelve $(n=12)$ whereas the number of female teachers was ten $(n=10)$. Since the participants' gender was not among the aims of this study, its probable effects were controlled. The researcher had the teachers fill in the questionnaire. Then, they were interviewed in their free times most often outside the university. The participants held M. A. and $\mathrm{PhD}$ degrees in different disciplines such as Chemistry, Accounting, Mathematics, and Law, to name a few.

\section{Instruments}

Besides the background questionnaire, two instruments were exerted in order to elicit both reliable and valid data. Since there were no previous studies on ESP teachers' beliefs and attitudes, attempts were made to develop a new questionnaire. The questionnaire was, as a result, taken from several related previous studies (i. e., Prodromou, 2002; Sherkatolabbasi et al., 2012; etc) and was fairly entirely modified to conform to the present study's contextual elements. The new questionnaire included 30 items on a Likert scale to elicit teachers' beliefs and attitudes concerning the teaching ESP. there were five choices for each item the most appropriate of which the participants were asked to circle as the one they believed to be true in their view. The choices for each of the 30 items were as follows: 1) Totally agree 2) agree 3 ) neither agree nor disagree 4) disagree 5) totally disagree.

Items included in this questionnaire underline the concepts such as the role of L1 in language teaching, the correction of errors, type and time of assessment, the students' needs, educational policies, classroom actions and practices, teaching materials, etc. the reliability of the questionnaire was calculated through Cronbach Alpha formula and the result pointed to 0.72 .

\section{Procedure}

In this study both qualitative and quantitative techniques were utilized. The 30-item-questionnaire was first administered to 22 participants each at a time. Next, semi-structured interviews were conducted with the teachers a week after the questionnaire had been administered and audio recorded.

\section{Data Analysis}

After the process of data collection, the obtained data were analyzed. The process of the data collection followed these 
steps: All participants' filled questionnaires were rated and analyzed and the frequencies of each choice (1) Totally agree 2 ) agree 3 ) neither agree nor disagree 4) disagree 5) totally disagree) were calculated for all the 30 items. Later, obtained frequencies of all items were converted to percentages to determine the overall value for each one of the questionnaire items. Finally, the obtained frequencies and percentages were put into tables for better depiction and further analytic decisions. The interviews were also transcribed and analyzed to come up with teachers own ideas that may have gone unnoticed in the questionnaire items. Since the interview questions were mainly adopted from the questionnaire items, their analysis was incorporated into the results of the questionnaire.

\section{DISCUSSION AND CONCLUSION}

The results of the data analysis from the questionnaire are shown in the Tables 1 and 2 .

\section{Result and Discussion}

To begin with the questionnaire items, the first one inquired whether the ESP course should be taught only by subject matter teachers. As the tables above indicate, $45 \%$ of participants agreed with this view, while $18 \%$ of participants didn't have any idea and $32 \%$ of them disagreed. However, the majority of teachers took side with the idea pr in proposed in the first item. The second item examined teachers' beliefs about translating the keywords and specialized passages into Persian and the necessity of having a student's listen to the teacher. The results indicated that 64 percent of them disagreed, 23\% strongly disagreed while $14 \%$ agreed.

The third question inquired teachers' beliefs about the role of teacher as an absolute authority in the classroom, the one who enjoys the central position in the classroom. $50 \%$ of the participants strongly disagreed and $41 \%$ disagreed with this idea. And $9 \%$ of participants agreed with this item. As with the fourth question in the questionnaire, almost all the teachers strongly agreed; i. e., 96\%. The reasons behind this lack of congruence relates to ESP teacher training courses and their experiences as students.

The fifth question centered on the inclusion of students' opinions and interests in classroom discussions. This item was, in a way, a cross-check of the third item as well. $41 \%$ of respondents strongly agreed with this item; $32 \%$ agreed with it while an only $9 \%$ of them disagreed. The next item focused on the notion of adjusting and adapting the difficulty level of materials (items) to students' different levels of general English proficiency, a belief with which $68 \%$ of participants agreed and 18\% disagreed. The seventh item read as, "it is a good idea to have a general English teacher and the subject matter teacher teach ESP collaboratively". Surprisingly enough, $60 \%$ of the participants disagreed with this idea and $14 \%$ strongly rejected it. The next item drew upon meeting the students' needs and expectations with which $77 \%$ of participants strongly agreed, $23 \%$ agreed.
Table 1. The frequencies of the five choices of individual items of the questionnaire

\begin{tabular}{lccccc}
\hline Items & $\begin{array}{c}\text { Strongly } \\
\text { agree }\end{array}$ & Agree & Neutral & Disagree & $\begin{array}{c}\text { Strongly } \\
\text { disagree }\end{array}$ \\
\hline 1 & 1 & 10 & 4 & 7 & 0 \\
2 & 0 & 3 & 0 & 14 & 5 \\
3 & 0 & 2 & 0 & 9 & 11 \\
4 & 21 & 1 & 0 & 0 & 0 \\
5 & 9 & 7 & 4 & 2 & 0 \\
6 & 2 & 15 & 1 & 4 & 0 \\
7 & 0 & 3 & 3 & 13 & 3 \\
8 & 17 & 5 & 0 & 0 & 0 \\
9 & 14 & 7 & 1 & 0 & 0 \\
10 & 5 & 11 & 1 & 4 & 1 \\
11 & 19 & 2 & 1 & 0 & 0 \\
12 & 6 & 16 & 0 & 0 & 0 \\
13 & 3 & 11 & 2 & 6 & 0 \\
14 & 0 & 2 & 2 & 10 & 8 \\
15 & 2 & 4 & 6 & 9 & 1 \\
\hline
\end{tabular}

Table 2. The percentages of the five choices of individual items of the questionnaire

\begin{tabular}{lccccc}
\hline Items & $\begin{array}{c}\text { Strongly } \\
\text { agree }\end{array}$ & Agree & Neutral & Disagree & $\begin{array}{c}\text { Strongly } \\
\text { disagree }\end{array}$ \\
\hline 1 & 4 & 45 & 18 & 32 & 0 \\
2 & 0 & 14 & 0 & 64 & 23 \\
3 & 0 & 9 & 0 & 41 & 50 \\
4 & 96 & 4 & 0 & 0 & 0 \\
5 & 41 & 32 & 18 & 9 & 0 \\
6 & 9 & 68 & 4 & 18 & 0 \\
7 & 0 & 14 & 14 & 59 & 14 \\
8 & 77 & 23 & 0 & 0 & 0 \\
9 & 64 & 32 & 4 & 0 & 0 \\
10 & 23 & 50 & 4 & 18 & 4 \\
11 & 86 & 9 & 4 & 0 & 0 \\
12 & 27 & 73 & 0 & 0 & 0 \\
13 & 14 & 50 & 9 & 27 & 0 \\
14 & 0 & 9 & 9 & 45 & 36 \\
15 & 9 & 18 & 27 & 41 & 4 \\
\hline
\end{tabular}

The $9^{\text {th }}$ item stressed the use of materials (textbooks, articles, etc.) appropriate to the students' specific needs and language ability. Almost all the teachers agreed with the implementation of relevant materials in ESP classes. In more statistical terms, $64 \%$ of respondents strongly agreed with this, $32 \%$ agreed with it and the left $4 \%$ were neutral.

Item no 10 read as "I believe ESP teachers should make use of the students' mother-tongue so as to foster their comprehension." $50 \%$ of participants took side with this idea and $23 \%$ of them strongly agreed with it while $23 \%$ disagreed. The next item in the questionnaire inquired the use of realia 
and instructional aids such as charts, diagrams, pictures and other instructional aids in ESP classes with which $95 \%$ of participants to excite. Item 12 focused on the actual presentation of the content to be taught. Almost all the participants agreed with this item. The next item in the questionnaire inquired the ESP teachers' beliefs about testing. $64 \%$ of the participants agreed with the view that ESP tests should the only contain subject matter related items without any considerable items testing general English proficiency.

Item no 14 examines the importance of memorizing the materials with which $82 \%$ of participants disagreed. The next item asked, "should the ESP teachers have the students speak and write in English?" almost half of the participants disagree with this view; $27 \%$ were neutral end to a $7 \%$ agree he read in reality, the teachers do not ask the students to speak and write in English.

\section{Discrepancies between Teachers' Beliefs and Actions}

Primarily, the actions carried out by teachers in ESP classes were merely based on the principles of Grammar Translation Method (GTM) of language teaching, the method which puts considerable amount of emphasis on mechanical drills, translation skills, grammar and vocabulary knowledge, memorization and reading. Interesting in this regard is the observation that the subject matter teachers who might have never heard of GTM we're following its principles in action. This can be explained by the very fact that these teachers were acting based on the previous learning experience when they were students here it is most likely that the ESP teachers were basing their actions on the methods with which they were taught in their language classes previously.

Another explanation for the actions taken by the teachers in this study comes from the idea that the students are reluctant to adapt themselves to new methodologies, if any, implemented by the teacher. Obviously, students who attend ESP classes do not expect anything different from what they have experience in general English courses. The results of observations as discussed above indicate considerable degrees of discrepancies between ESP teachers' beliefs and their actions.

\section{CONCLUSION}

This study examined the Iranian ESP teachers' beliefs and their ties with classroom practices. The findings out of the study revealed that there was no relationship between ESP teachers' beliefs on their teaching practices in the classroom. In fact, ESP teachers' actions and classroom practices are a reflection of their beliefs about learning and teaching. Overall, the present investigation broadens the scope of the studies dealing with teachers' beliefs and attitudes. The findings of the presents study are significant on the accounts that no previous study to date has examined the beliefs of Iranian ESP teachers. In sum, different beliefs of ESP instructors were examined along with their actual classroom practices. In fact, there is a close relationship between the respondents' past learning experiences and their beliefs towards teaching ESP.
One of the important themes quite related to ESP teachers' beliefs and practices is the use of appropriate materials. The materials' contents may be either irrelevant to the proficiency level of the students or are not in accordance with the students' needs. Moreover, the materials may be written in such a way to maximize a limited number of skills and subskills. Such is the case with the ESP materials in the Iranian context where the reading skill is given too much credit. Under such circumstances ESP teacher face difficulty in reconciling their beliefs and actions. The ESP teachers' beliefs and attitudes seem to be vulnerable to many threats. For instance, the teaching method the ESP teachers strongly believe in may be replaced by the one the students appreciate. This exerts a direct effect on the ESP classroom actions as well such as teaching efficiency, classroom management, and conducting classroom activities. As far as the syllabus is concerned, in reality, the ESP teachers' beliefs and actions may not match completely as far as the syllabus is concerned. Most often, ESP teachers cannot implement their syllabus which might be designed based on their beliefs and attitudes due to some factors such as institutional constraints.

\section{REFERENCES}

Adelson, B. (1981). Problem solving and the development of abstract categories in programming languages. Memory \& Cognition, 9, 422-433.

Atai, M. R. (2002a). Iranian EAP programs in practice: A study of key methodological aspects. Sheikhbahaee ELT Journal, 1(2), 1-15.

Atai, M.R. (2002b). ESP methodology revisited: A genre-based reading comprehension course for the students of dentistry. Indian Journal of Applied Linguistics, 28(1), 77-90.

Basturkmen, H. (2006). Ideas and options in English for specific purposes. Mahwah, New Jersey: Lawrence Erlbaum Associates.

Berliner, D. C. (1986).In pursuit of the expert pedagogue. Educational Researcher, 15(7), 5-13.

Borg, M. (2001).Teachers' beliefs. ELT Journal, 55(2), 186-188.

Borg, S. (2003). Teacher cognition in language teaching: a review of research on what language teachers think, know, believe, and do. Language Teaching, 36(2), 81-109.

Borg, S. (1999). The use of grammatical terminology in the second language classroom: a qualitative study of teachers' practices and cognitions. Applied Linguistics, 20, 95-126.

Brindley, G. (2004).Needs analysis. In M. Byram (Ed.), Routledge Encyclopedia of language teaching and learning (pp.438-441).New York: Taylor and Francis.

Brown, J. D. (1995). The elements of language curriculum. Boston: Heinle and Heinle.

Crystal, D. (2003). English as a global language (2 ${ }^{\text {nd }}$ ed.). New York: Cambridge UP.

Dreyfus, H. L., \& Dreyfus, S. E. (1986).Mind over machine. New York: Free Press.

Dudley-Evans, T. (1998). Developments in English for Specific Purposes: A multi-disciplinary approach. Cambridge University Press. 
Dudley-Evans, T. \& St John, M. J. (1998).Developments in English for specific purposes: A multi-disciplinary approach. Cambridge: Cambridge University Press.

Fakharzadeh, M. (2000). Analyzing discoursal and formal needs of students of Psychology and sociology. Unpublished MA thesis. University of Isfahan, Isfahan, Iran.

Farhady, H. (2006). Reflections on and directions for ESP materials development in SAMT.In Kiani\&Khayamdar (Eds.), Proceedings of the First National ESP/EAP Conference, Volume 3. Tehran: SAMT Publication.

Ferris, D. R., Pezone, S., Tade, C. R., \&Tiniti, S. (1997). Teacher commentary on student writing: Descriptions and implications. Journal of Second language writing, 6,155-182.

Ferris, D. R., \& Roberts, B. (2001). Error feedback in L2 writing classes: How explicit does it need to be? Journal of Second Language Writing, 10, 161-184.

Grossman, P. L. (1995). A psychological view of teachers: Teachers' knowledge. In L. W. Anderson (Ed.), International encyclopedia of teaching and teacher education ( $2^{\text {nd }}$ ed.). Oxford: Pergamon.

Howatt, A. P. R. (2004). A History of English Language Teaching. ( $2^{\text {nd }}$ ed.). Oxford: OUP.

Hutchinson, T. (1988). Making materials work in the ESP classroom. In D. Chamberlain \& R. J. Baumgardner (Eds.), ESP in the classroom: Practice and evaluation. ELT Documents 128 (pp. 71-75).

Hutchinson, T., \& Waters, A. (1987). English for specific purpose: A learning-centered approach. Cambridge: Cambridge University Press.

Johnson, K. (1994). The emerging beliefs and instructional practices of pre-service English as a second language teachers. Teaching and Teacher Education, 10(4), 439-452.

Johnson, K. (1982). Communicative syllabus design and methodology. Oxford: Pergamon.

Mazdayasna, G. (2008). Developing a profile of the ESP needs for the students of medical and midwifery in Iran. Unpublished Ph.D. dissertation. University of Isfahan, Isfahan, Iran.

Pajares, M. F. (1992). Teachers' beliefs and educational research: Cleaning up a messy construct. Review of Educational Research. 62, 307-332.

Peacock, M. (2001). Pre-service ESL teachers' beliefs about second language learning: A longitudinal study. System, 29(2), 177-195.

Prodromou, L. 2002. From Mother Tongue to Other Tongue. Retrieved 22 October 2012 from: http://www.geocities. com/cgabrielatos/Bone.

Rajabi, P., Kiani, G., \& Maftoon, P. (2012). ESP in-service teacher training programs: Do they change Iranian teachers' beliefs, classroom practices and students' achievements? Ibérica, 24, 261-282.
Renzaglia, A., Hutchins, M., \& Lee, S. (1997). The impact of teacher education on the beliefs, attitudes, and dispositions of pre-service special educators. Teacher Education and Special Educations, 4, 360-377.

Richards, J. (2001). Curriculum development in language teaching. Cambridge: Cambridge University Press.

Richards, J. C., Platt, J., \& Platt, H. (1992). Longman dictionary of language teaching and applied linguistics (2ed edition). UK: Richard Clay plc, Bungay.

Richards, J., \& Schmidt, R. (2002).Longman dictionary of language teaching and applied linguistics $\left(3^{\text {rd }} \mathrm{ed}\right.$.). London: Longman.

Robinson, P. C. (1991). ESP today: A practitioner's guide. Englewood Cliffs, NJ: Prentice Hall.

Ryan, P. 2004. Teacher thinking. In M. Byram (Ed), Routledge encyclopedia of language teaching and learning (pp. 610-616). New York: Taylor and Francis.

Strevens, P. (1992). English as an international language: Directions in the 1990s. In B. B. Kachru (Ed.), The other tongue: English across cultures (pp. 27-47). Urbana: University of Illinois Press.

Strevens, P. (1988). The learner and teacher of ESP. In D. Chamberlain \& R. J. Baumgardner, (Eds.), ESP in the classroom, practice and evaluation. ELT Documents, 128 (pp. 39-44).

Strevens, P. (1980). Teaching English as an International Language: Practice to Principle. Pergamon Press.

Stuart, C., \& Thurlow, D. (2000).Making it their own: Pre-service teachers' experiences, beliefs, and classroom practices, Journal of Teacher Education, 51(2), 112-121.

Swales, J. (2000).Languages for specific purposes. Annual Review of Applied Linguistics, 20, 59-76.

Swales, J. (1988). Episodes in ESP. Prentice Hall.

Varnosfadrani, W. \& Dabaghi, A. (2009). Teaching English for specific purposes. In: Reinelt, R. (Ed.), Into the next decade with (2nd) FL teaching (pp.181-201). Rudolf Reinelt Research Laboratory EU Matsuyama, Japan.

Waters, A. (1988). ESP: Back to the future! Especialist, 9(1), 27-43.

Widdowson, H. G. (1990). Aspects of language teaching. Oxford: Oxford University Press.

Woods, D. (1996). Teacher cognition in language teaching: Beliefs, decision-making, and classroom practice. Cambridge: Cambridge University Press.

Yarmohammadi, L. (2005). ESP in Iran from language planning perspective. Proceedings of the First National ESP/EAP Conference, Volume 2.Tehran: SAMT Publications.

Zacharias, N. T. (2003). 'A survey of tertiary teachers' beliefs about English language teaching in Indonesia with regard to the role of English as a global language'. Unpublished MA thesis. Assumption University of Thailand: Institute for English Language Education. 